\author{
S.I. Kabanikhin ${ }^{1}$, K.T. Iskakov ${ }^{2,4, *}$, D.K. Tokseit ${ }^{3}$, M.A. Shishlenin ${ }^{1}$, A. Toibekov ${ }^{2}$ \\ ${ }^{1}$ Novosibirsk State University, Novosibirsk, Russia; \\ ${ }^{2}$ L.N.Gumilyov Eurasian national University, Nursultan, Kazakhstan; \\ ${ }^{4}$ National Research Nuclear University MEPhl (Moscow Engineering Physics Institute); \\ ${ }^{3}$ Karaganda Industrial University, Temirtau, Kazakhstan \\ (E-mail: ksi52@mail.ru,kazizat@mail.ru,tokseit1990@gmail.com,mshishlenin@ngs.ru,aidyn86kar@mail.ru)
}

\title{
Problem of describing the function of a GPR source
}

\begin{abstract}
In this paper, we consider the problem of determining the source $h(t) \delta(x)$ of electromagnetic waves from GPR data. The task of electromagnetic sensing is to find the pulse characteristic of the medium $r(t)$ and consists in calculating the response of the medium to the pulse source of excitation $\delta(t)$ (Dirac Delta function). To determine the analytical expression of the impulse response of a homogeneous medium $r(t)$, we use the method proposed in [1-2]. To determine $h(t)$, the inverse problem is reduced to a system of Volterra integral equations. The source function $h(\tau)$, is defined as the solution of the Volterra integral equation of the first kind, $f(t)=\int_{0}^{t} r(t-\tau) h(\tau) d \tau$ in which $f(t)$ is the data obtained by the GPR at the observation points. The problem of calculating the function of the GPR source $h(\tau)$ consists in numerically solving the inverse problem, in which the function of the source $h(\tau)$ is unknown, and the electromagnetic parameters of the medium are known: the permittivity $\varepsilon$; the conductivity $\sigma$; the magnetic permeability $\mu$ and the response of the medium to a given excitation $h(\tau)$.
\end{abstract}

Keywords: radargram processing, source recovery, mathematical simulation, calculation results.

\section{Introduction}

Ground-penetrating radars have builtin software, the output of which is a radarogram, i.e. time scans of the reflected signal taken along the route. To interpret radarograms, engineering techniques are used, and it also depends on the geophysicist's experience and skills in reading radarograms. On the other hand, there is a different direction of interpretation of radarograms, based on mathematical and computer modeling of the propagation and reflection of electromagnetic waves in the medium. The radarogram is a function of the run time to inhomogeneity. In practice, geophysicists are interested in the physical characteristics of inhomogeneities that depend on spatial coordinates. For the numerical solution of the inverse coefficient problem, it is necessary to have a table value of the source of the disturbance, as well as table values of the reflected signals (medium responses) at the measurement points. To solve these problems, we have developed an algorithm for restoring the source, and as a result, determining the response of media corresponding to real GPR data at observation points. Here is a brief overview of the work related to these problems. Questions of uniqueness of the solution of inverse coefficient problems are studied in [3]. Numerical algorithms for solving such a class of inverse problems are described in [4], which also studies the convergence of iterative methods for determining coefficients for hyperbolic equations. The problem of restoring the source of a tsunami is considered in $[5]$.

In [6], we consider the inverse problem of identifying a source that depends on the spatial variable $F(x)$ in the one-dimensional wave equation $u_{t t}=c^{2} u_{x x}+F(x) H\left(t-\frac{x}{c}\right)$, $(x, t) \in\{(x, t) \mid x>0,-\infty \leq t \leq T\}$. The measured data is taken as $g(t):=u(0, t)$. The relationship between this task and the GPR data interpretation task is shown. An iterative algorithm for restoring an unknown source $F(x)$ is developed. The algorithm is based on the decomposition of $F(x)$ functions

\footnotetext{
* Corresponding author.

E-mail: kazizat@mail.ru
} 
into a Fourier series and representation of the solution of a direct problem using the $F(x)$ function. Next, we solve the minimization problem for the discrete form of the Tikhonov functional, which is reduced to a linear algebraic system and solved numerically. Calculations show that the proposed algorithm allows reconstructing the x-dependent $F(x)$ source with sufficient accuracy for clean and noisy data.

In [7], it was assumed that a function $\mathrm{h}(\mathrm{t})$ of a special type was defined for each carrier frequency. Assuming that the coefficients of dielectric, magnetic permeability, and conductivity are smooth functions, a fundamental solution for the system of the Maxwell equation is constructed in [8]. The original problem is reduced to an auxiliary problem for vector and scalar potentials. In [9], we derive a formula for solving the Cauchy problem of a multidimensional Telegraph equation, which allows us to reduce the problem to quadrature forms and obtain exact solutions explicitly. Later, using these formulas, we can obtain formulas for calculating the impulse response of an arbitrary sufficiently smooth medium.

The need to solve inverse coefficient problems for hyperbolic equations follows from practical applications that arise in problems of seismology, electrical exploration, tomography, rock mechanics, archeology, and many problems of natural science. A class of questions of existence, uniqueness of solutions, regularization and stability are considered in a series of works by scientists from near and far abroad (see, for example, [10]-[24]). Algorithms for numerical solutions of coefficient inverse problems for hyperbolic equations are covered in monographs [15]-[17].

Note that the development of interpretation methods is still in demand in geophysical research. As noted above, in practice, the inverse problems that arise in georadar methods are solved by various approximate methods, the most commonly used ones are described in [25] and in the review [26]. To study the horizontally-layered media are used for economical methods of solution of direct problems of radar. This method is based on the method of layer-by-layer recalculation, which was proposed in [27], and was further improved in [28]-[29]. This algorithm was used for electrical exploration and elasticity problems in [30]-[33].

\section{Description of the method}

The problem of accurately describing the GPR source function occurs in all known GPR series produced. An approximate value of the source function leads to an error in interpreting the GPR data.

One of the reasons that leads to an inaccurate description of the GPR source is the effect of a pulse of the order of 10 nanoseconds. It is almost impossible to measure the amplitude of the pulse carrier in the specified time interval.

Note also that knowledge of the source function is necessary to solve the inverse problem, since effective algorithms are constructed not for the function $f(t)$ that is the response of the medium, radar data from the source $h(t)$, but for the $r(t)$ pulse characteristic of the medium perturbed by the Delta function $\delta(t)$ of the source.

The proposed method for determining the functions of the GPR source $h(t)$ is based on the numerical solution of the inverse problem, in which the function of the source $h(t)$ is unknown, and the electromagnetic parameters of the medium are known: the permittivity $\varepsilon$, magnetic permeability $\mu$, conductivity $\sigma$, and the response of the medium to a given excitation $h(t)$.

We give to the description of the mathematical model. Let us consider the problem statement formulated and studied in monographs $[3,4]$ for the geoelectric equation:

$$
\begin{gathered}
\mu \varepsilon \omega_{t t}=\omega_{z z}+\omega_{x x}-\mu \sigma \omega_{t}+\delta(t) \delta(z) \eta(x) \\
\left.\omega\right|_{t<0}=0,\left.\omega_{t}\right|_{t<0}=0 \\
\omega(0, x, t)=r(x, t)
\end{gathered}
$$

Here: $\varepsilon$ is permittivity, $\mu$ is magnetic permittivity, 
$\sigma$ is medium conductivity, $\delta(t)$ is Dirac Delta function, $r(x, t)$ is an impulse response of the medium,

We introduce the equation of geoelectrics, in which electromagnetic waves are excited by the source of the GPR $h(t)$ :

$$
\begin{gathered}
\mu \varepsilon \omega u_{t t}=u_{z z}+u_{x x}-\mu \sigma u_{t}+\delta(z) \eta(x) h(t) \\
\left.u\right|_{t<0}=\left.0 u_{t}\right|_{t<0}=0 \\
u\left(0, x^{*}, t\right)=f\left(x^{*}, t\right)
\end{gathered}
$$

Here: $h(t)$ is a function describing the GPR source as a function of time, $f\left(x^{*}, t\right)$ is a the response of the medium at the observation point $x^{*}$ (the radarogram trace).

To determine the impulse response of the medium, we consider the Volterra equation of the first kind:

$$
f(x, t)=\int_{0}^{t} r(x, t-\tau) h(\tau) d \tau
$$

In this equation, the left side is known, i.e. the radar data at the observation point. The $h(t)$ is a function describes the radar source. The relation (7) shows the relationship between the response of the medium, which is a trace of the solution of the problem (4)-(6) and the impulse response (3). Obviously, it is advisable to determine the impulse response $r(x, t)$ analytically. For this purpose, in the future we use the method of solving the direct problem (1)-(3), with constant coefficients, given in [1]. To analyze the numerical algorithm, we conduct experimental studies in a homogeneous medium with known geoelectric properties.

Analytical method for determining the impulse response

Following [34], we denote:

$$
a_{0}^{2}=\frac{1}{\mu \varepsilon}, a_{1}=-\frac{\sigma}{\varepsilon}
$$

Then, taking into account the notation (8), we write problem (1)-(3) in the form:

$$
\begin{gathered}
\omega_{t t}=a_{0}^{2}\left(\omega_{z z}+\omega_{x x}\right)+a_{1} \omega_{t}-a_{0} \delta(t) \delta(z) \eta(x) \\
\left.\omega\right|_{t<0}=,\left.\omega_{t}\right|_{t<0}=0 \\
\omega(0, x, t)=r(x, t)
\end{gathered}
$$

Let's introduce a new function $\vartheta$ instead of $\omega$ using the formula

$$
\omega=e^{\alpha t} \vartheta
$$

Assuming $\alpha=\frac{1}{2} a_{1}, c^{2}=-\alpha^{2}+2 a_{1}$ from the relations (9)-(10), we get :

$$
\begin{gathered}
\vartheta_{t t}=a_{0}^{2}\left(\vartheta_{z z}+\vartheta_{x x}\right)+c^{2} \vartheta+a_{0} \eta(x) \delta(t) \\
\left.\vartheta\right|_{t<0}=0,\left.\vartheta_{t}\right|_{t<0}=0
\end{gathered}
$$

Next, to get an explicit analytical expression for the impulse response of the medium, we use the method of work [1].

We decompose the following functions into a Fourier series in the system of function $\left\{e^{i j x}\right\}$.

$$
\vartheta(x, z, t)=\sum_{y} \vartheta^{j}(z, t) e^{i j x}
$$




$$
\eta(x)=\sum_{j} \eta_{j} e^{i j x}
$$

Then be

$$
\left(\vartheta_{t t}^{j}-a_{0}^{2} \vartheta_{z z}+\left(\lambda^{j}\right)^{2} \vartheta^{j}-c^{2} \vartheta^{j}\right)=\eta_{j}(z) \delta(t)
$$

Finally, after performing a series of calculations of relations (9)-(10), we write it differently:

$$
\begin{gathered}
\vartheta_{t t}^{j}-a_{0}^{2} \vartheta_{z z}^{j}+\left(\lambda^{j}\right)^{2} \vartheta^{j}=0 \\
\left.\vartheta^{j}\right|_{t<0}=0,\left.\vartheta_{t}^{j}\right|_{t<0}=0 \\
{\left[\vartheta_{z}\right]_{z=0}=a_{0} \eta^{j} \delta(t)}
\end{gathered}
$$

By analogy, after applying the Fourier transform, condition (11) has the form

$$
\begin{gathered}
\vartheta(0, x, t)=r(x, t)=\sum_{j} r_{j}(t) e^{i j x} \\
\vartheta^{j}(0, t)=r^{j}(t)
\end{gathered}
$$

Solution of problem (12)-(14) have the form

$$
\vartheta^{j}(z, t)=\frac{1}{2}-a_{0} \eta^{i}(0) J_{0}\left(\lambda^{j} \sqrt{t-z^{2}}\right)
$$

Assuming $z=0$,in expression (15), we obtain an explicit analytical expression for the impulse response of the medium:

$$
r^{j}(t)=-J_{0}\left(\lambda^{j} t\right) \lambda^{j} \eta_{0}^{j} j=1, N
$$

\section{A description of the method in the General case}

In [9], a formula for solving the Cauchy problem for a linear Telegraph equation in three-dimensional space is derived and the Kirchhoff formula for a linear wave equation that passes into it at zero conductivity. Reducing the problem of the field of a given is derived external current source in an infinite homogeneous isotropic conductor to a generalized Cauchy problem for a three-dimensional Telegraph equation is considered, which allows us to reduce this problem to quadratures, and in some cases to obtain accurate three-dimensional solutions with a propagating front, which are of great applied value for testing methods for the numerical solution of Maxwell's equations. As an example, an exact solution to the problem of the field of the Hertz electric dipole with an arbitrary dependence of the current on time in an infinite homogeneous isotropic conductor is constructed is constructed.

Let us present formulas for solving the Cauchy problem for the telegraph equation described in [9]. The Cauchy problem for the spatially three-dimensional linear telegraph equation is considered, the formulation of which is completely similar to that for the wave equation

$$
\begin{gathered}
L E_{T}=\frac{\partial^{2}}{\partial t^{2}} E_{T}+\lambda_{\delta} \frac{\partial}{\partial t} E_{T}-c^{2} \Delta E_{T}=\delta(x, t), \quad x \in R^{3}, t>0 \\
\left.E_{T}(x, t)\right|_{t=0}=E_{T}^{0}(x),\left.\quad \frac{\partial}{\partial t} E_{T}(x, t)\right|_{t=0}=\left(E_{T}\right)_{t}^{0}(x), \quad x \in R^{3}
\end{gathered}
$$


Here: $\lambda_{\delta}>0, c>0$ are set constants, $\delta(x, t)$ is the Delta function, $E_{T}(x, t),\left(E_{T}\right)_{t}^{0}(x)$ are set functions. Then the exact solution of problem (16)-(17) for a spatially three-dimensional linear Telegraph equation has the form:

$$
E_{T}(x, t)=e^{-\frac{1}{2} \lambda_{\delta} t}\left(\frac{\theta(t)}{4 \pi c^{2} t} \delta_{S_{c t}}(x)+\frac{\omega \theta(t) \theta(c t-|x|)}{4 \pi c^{2} \sqrt{(c t)^{2}-|x|^{2}}} J_{1}\left(\frac{\omega}{c} \sqrt{(c t)^{2}-|x|^{2}}\right)\right)
$$

Here: $\theta(t)$ is a theta function, $\delta_{S_{c t}}(x)$ is a simple layer on the sphere $S_{c t}=\{x:|x|=c t\}$ with density $1, \lambda_{\delta}=\frac{\delta}{E E_{0}}$.

In [8], a fundamental solution for the system of the Maxwell equation is constructed.

$$
\begin{aligned}
& \text { rot } H=\varepsilon\left(\frac{\partial}{\partial t} E+\sigma E\right)+j^{0} \delta\left(x-x^{0}\right) \delta(t), x^{0} \in R^{3} \\
& \text { rot } H=-\mu \frac{\partial}{\partial t} H,(x, t) \in R^{4}
\end{aligned}
$$

on the construction of its generalized solution satisfying the conditions

$$
\left.H\right|_{t<0}=\left.E\right|_{t<0}=0 .
$$

Assuming that $\varepsilon, \mu, \sigma$ are smooth functions of the point $x \in R^{3}, \varepsilon>0, \mu>0$,

$$
j=j^{0} \delta\left(x-x^{0}\right) \delta(t), x^{0} \in R^{3},
$$

$j^{0}$ is some numeric vector, $\delta$ is the Dirac Delta function. We consider the vector potential

$$
H=\frac{1}{\mu} \operatorname{rot} A, \quad E=-\frac{\partial}{\partial t} A-\nabla \varphi
$$

Here the Lorentz gauge condition is

$$
\operatorname{div} A+\varepsilon \mu\left(\varphi_{t}+\sigma \varphi\right)=0,\left.\quad \varphi\right|_{t<0}=0 .
$$

The scalar potential is found through the vector by the formula

$$
\varphi\left(x, t, x^{0}\right)=-\frac{1}{\varepsilon(x) \mu(x)} \int_{0}^{t} e^{\sigma(x)(z-t)} \operatorname{div} A\left(x, z, x^{0}\right) d z,
$$

Problem (19) - (21) is reduced to some auxiliary problem, for vector (22) and scalar potentials $\mathrm{A} A, \varphi$ : (see $(23)-(24))$

For a vector potential, the Cauchy problem is studied:

$$
\begin{gathered}
L A \equiv \frac{\partial^{2}}{\partial t^{2}} A+\sigma \frac{\partial A}{\partial t}-\frac{1}{\varepsilon \mu} \mid \Delta A+\frac{1}{\varepsilon} \nabla \frac{1}{\mu} \times \operatorname{rot} A- \\
-\nabla\left(\frac{1}{\varepsilon \mu}\right) \operatorname{div} A+\frac{1}{\varepsilon \mu} \nabla \sigma \int_{0}^{t} e^{\sigma(x)(z-t)} \operatorname{div} A\left(x, z, x^{0}\right) d z=\frac{1}{\varepsilon} j, \\
\left.A\right|_{t<0}=0 .
\end{gathered}
$$

\section{Conclusions}

When numerically modeling the solution of the inverse coefficient problem, the question arises about the table value of the source of the disturbance, as well as the table value of the reflected signals (medium responses), at the measurement points. To solve these issues, we have developed an algorithm for restoring the source. Next, it is necessary to carry out measurements using ground-penetrating radar in a homogeneous environment, for example, a sand pit with known geoelectric properties. The response of the medium obtained by georadar from a test environment is used to calculate the table 
values definition source excited by the GPR. Then the obtained source value is used in algorithms for determining the geoelectric section of the object under study. The authors of this article have developed a series of algorithms for the numerical solution of inverse and ill-posed problems, and they can be found in published monographs and scientific articles [3, 4, 6, 20].

In General, using exact formulas (18) for solving the Cauchy problem for a spatially three-dimensional linear Telegraph equation, one can obtain formulas for calculating the impulse response of an arbitrary sufficiently smooth medium.

The work was supported by a grant from the Ministry of education and science of the Republic of Kazakhstan under contract No. 132 dated 12.03.2018 under the project AR05133922 and KPFI SB RAS project No. 26.

\section{References}

1 Благовещенский А.С. Об одной задаче распространения волн в полубесконечном нерегулярном волноводе / А.С. Благовещенский, С.И. Кабанихин // Дифференциальные уравнения. - 1983. - 19. - № 4. - С. 603-607.

2 Кабанихин С.И. Обратные задачи для гиперболических уравнений и конечно-разностные методы их исследования / С.И. Кабанихин // Дис. канд. физ.-мат. наук. - Новосибирск, 1978. - C. 100.

3 Романов В.Г. Обратные задачи геоэлектрики / В. Г. Романов, С.И. Кабанихин. - М.: Наука, 1991. - 303 c.

4 Кабанихин С.И. Оптимизационный метод решения коэффициентных обратных задач С.И. Кабанихин, К.Т. Искаков. - Новосибирск: НГУ, 2001. - 316 с.

5 В.Г.Романов. Одномерная обратная задача об определении источника цунами / В.Г. Романов, П.С. Мошкалев // Сиб. журн. индустриальной математики. - 2011. - 14. - №3. - С. $87-99$.

6 Mukanova B.G. Inverse source problem for wave equation and GPR data interpretation problem / B.G. Mukanova, V.G. Romanov // Eurasian Journal of Mathematical and Computer Applications. - 2016. - 4. - No. 3. - P. 15-28.

7 Iskakov K.T. Creation and testing of a new mathematical software for processing georadar data / K.T. Iskakov, D.K. Tokseit, Zh.O. Oralbekova, T. Mirgalikyzy // Eurasian Journal of Mathematical and Computer Applications. - 2019. - 7. - No. 4. - P. 86-99.

8 Романов В.Г. О структуре фундаментального решения задачи Коши для системы уравнений Максвелла / В.Г. Романов / / Дифференциальные уравнения. - 1986. - 22. - № 9. - С. 15771587.

9 Ахметов О.И. Решение задачи Коши для трехмерного телеграфного уравнения и точные решения уравнений Максвелла в однородном изотропном проводнике с заданным источником внешнего тока / О.И. Ахметов, В.С. Мингалев, И.В. Мингалев, О.В. Мингалев // Журн. вычислительной математики и математической физики. - 2018. - 58. - С. 618-625.

10 Cannon J.R. An inverse problem for an unknown source term in a wave equation / J.R. Cannon and P. DuChateau // SIAM Journal on Applied Mathematics. - 1983. - 43. - No. 3. - C. 553564.

11 Chapouly M. Distributed source identification for wave equations: An off-line observer-based approach / M. Chapouly, M. Mirrahimi // Automatic Control, IEEE Trans. - 2012. - 57 № 8. - P. 2076-2073.

12 Deguenon J. Infinite dimensional observers for vibrating systems / J. Deguenon, G. Sallet, C.-Z. Xu // in Proc. IEEE Conf. on Decision and Control. - 2006. - P. 3979-3983. 
13 Isakov V. Inverse Source Problem / V. Isakov // Mathematical Surveys and Monographs. American Mathematical Society, 1990. - 34.

14 Kabanikhin S.I. Inverse and Ill-Posed Problems / S.I. Kabanikhin // Theory and Applications. - De Gruyter. Germany, 2011.

15 Kabanikhin S.I. Direct Methods of Solving Multidimensional Inverse Hyperbolic Problem / S.I. Kabanikhin, A.D. Satybaev and M.A. Shishlenin // VSP. - Utrecht. - 2004.

16 Kabanikhin S.I. Inverse and ill-posed problems for hyperbolic equations / S.I. Kabanikhin, K.T. Iskakov // KazNPU. - Almaty, 2007.

17 Beilina L. Approximate Global Convergence and Adaptivity for Coefficient Inverse Problems / L. Beilina and M.V. Klibanov. - New York: Springer, 2012.

$18 \mathrm{~V}$ de Hoop M. An inverse source problem for a variable speed wave equation with discrete-in-time sources / Maarten V de Hoop, J.Tittelfitz // Inverse Problems. - 1. - No. 7. - 2015. - 075007.

19 Symes Rakesh W.W. Uniqueness for an inverse problem for the wave equation / W.W. Symes Rakesh // Communications in Partial Differential Equations. - 1988. - 13. - P. 87-96.

20 Romanov V.G. Inverse Problems for Maxwell's Equations. / V.G. Romanov, S.I. Kabanikhin // Utrecht, The Netherlands: VSP. - 1994. - 249 p.

21 Tikhonov A. Solution of Ill-Posed Problems / A. Tikhonov, V. Arsenin. - Wiley, New York, 1977.

22 Hasanov A. Simultaneous determination of source terms in a linear hyperbolic problem from the final over determination: weak solution approach / A. Hasanov // IMA Journal of Applied Mathematics. - 2009. - 74. - P. 1-19.

23 Engl H.W. Uniqueness and stable determination of forcing terms in linear partial differential equations with over specified boundary data / H.W. Engl, O. Scherzer, M. Yamamoto // Inverse Problem. - 1994. - 10. - P. 1253-1276.

24 M. Yamamoto. Stability, reconstruction formula and regularization for an inverse source hyperbolic problem by a control method / M. Yamamoto // Inverse Problems. - 1995 - 11. - P. 481-496.

25 Stolt R.H. Migration by Fourier transform / R.H. Stolt // Geophysics. - 1978. - 43. - No. 1. - P. 23-43.

26 Özdemir Caner. A Review on Migration Methods in B-Scan Ground Penetrating Radar Imaging. / Caner Özdemir, Şevket Demirci, Enes Yiğit, Betül Yilmaz // Mathematical Problems in Engineering. - 2014. - 6. - Article ID 280738, http://dx.doi.org/10.1155/2014/280738.

27 Tikhonov A.N. Method for calculating electromagnetic fields excited by alternating current in layered media / A.N.Tikhonov, D.N. Shahsuvarov// Doklady AN, ser. Geophysical. - 1956. 3. - P. 251-254.

28 Dmitriev V.I. General method for calculating the electromagnetic field in a layered medium / V.I. Dmitriev // Computational methods and programming. - 1968. - 10. - P. 55-65.

29 Dmitriev V.I. Numerical studies of electromagnetic fields in layered media / V.I. Dmitriev, E.A. Fedorova // Computational methods and programming. - 1980. - 32. - P. 150-183.

30 Karchevsky A.L. A numerical solution to a system of elasticity equations for layered anisotropic media / A.L. Karchevsky // Russian Geology and Geophysics. - 2005. - 46. - No. 3. - P. 339351.

31 Karchevsky A.L. The direct dynamical problem of seismics for horizontally stratified media / A.L. Karchevsky // Siberian Electronic Mathematical Reports. - 2005. - 2. - P. 23-61.

32 Karchevsky A.L. A frequency-domain analytical solution of Maxwell's equations for layered anisotropic media / A.L. Karchevsky // Russian Geology and Geophysics. - 2007. - 48. No. 8. - P. 689-695. 
33 Karchevsky A.L. Analitical expressions for a solution of convective heat and moisture transfer equations in the frequency domain for layered media / A.L. Karchevsky, B.R. Rysbayuly // Eurasian Journal of Mathematical and Computer Applications. - 2015. - 3. - No. 4. - P. 5567.

34 Смирнов В.И. Курс высшей математики / В.И. Смирнов. - М.: Наука, 1974. - 2.

\author{
С.И. Кабанихин, Қ.Т. Искаков, Д.Қ. Тоқсеит, М.А. Шишленин, А. Тойбеков
}

\title{
Георадар дереккөзінің функциясын түсіндіру мәселесі
}

\begin{abstract}
Мақалада георадар мәліметтерінен электромагниттік толқындардың $h(t) \delta(x)$ дереккөзін анықтау мәселесі қарастырылды. Электромагниттік зондтаудың міндеттері $r(t)$ ортасының импульстік реакциясын табу болып табылады және ортаның импульстің қозу дереккөзіне реакциясын есептеп шығару $\delta(t)$ (Dirac delta функциясы). Авторлар біртекті $r(t)$ ортаның импульс реакциясының аналитикалық өрнегін анықтау үшін $[1,2]$ ұсынылған әдісті қолданды. $h(t)$ анықтау үшін кері есеп вольтердің интегралдық теңдеулер жүйесіне келтірілді. Функция бірінші типтегі Вольтерраның интегралдық теңдеуінің шешімі ретінде анықталды, $f(t)=\int_{0}^{t} r(t-\tau) h(\tau) d \tau$-де $h(\tau)-$ бұл GPR бақылау нүктелерінде алынған мәліметтер. GPR дереккөзі $h(\tau)$ функциясын есептеу есебі кері есепті сандық шешуден тарады, онда $h(\tau)$ дереккөзі функциясы белгісіз, ал ортаның электромагниттік параметрлері белгілі: өткізгіштік $\varepsilon$; өткізгіштік conductivity $\sigma$; магнит өткізгіштігі permeability $\mu$ және ортаның берілген қоздыруға реакциясы $h(\tau)$.
\end{abstract}

Kiлm сөздер: радарограмманы өңдеу, дереккөзді қалпына келтіру, математикалық модельдеу, есептеу нәтижелері.

\section{С.И. Кабанихин, К.Т. Искаков, Д.К. Токсеит, М.А. Шишленин, А. Тойбеков}

\section{Задача описания функции источника георадара}

В статье рассмотрена задача определения источника $h(t) \delta(x)$ электромагнитных волн по данным георадара. Задача электромагнитного зондирования заключается в нахождении импульсной характеристики среды $r(t)$ и состоит в вычислении отклика среды на импульсный источник возбуждения $\delta(t)$ (дельта-функция Дирака). Для определения аналитического выражения импульсной характеристики однородной среды $r(t)$ авторами использован метод, предложенный в $[1,2]$. Для определения $h(t)$ рассматриваемая обратная задача сводится к системе вольтеровских интегральных уравнений. Функция источника $h(\tau)$ определяется как решение интегрального уравнения Вольтерра первого рода $f(t)=\int_{0}^{t} r(t-\tau) h(\tau) d \tau$, в котором $f(t)$ - данные, полученные георадаром в точках наблюдения. Задача вычисления функции источника георадара $h(\tau)$ состоит в численном решении обратной задачи, в которой неизвестной является функция источника $h(\tau)$, а известными предстают электромагнитные параметры среды: диэлектрическая проницаемость $\varepsilon$; проводимость $\sigma$; магнитная проницаемость $\mu$ и отклик среды на заданное возбуждение $h(\tau)$.

Ключевые слова: обработка радарограммы, восстановление источника, математическое моделирование, результаты расчетов.

\section{References}

1 Blagoveshchenskii, A.S., \& Kabanikhin, S.I. (1983). Ob odnoi zadache rasprostraneniia voln v polubeskonechnom nereguliarnom volnovode [On one problem of wave propagation in a semiinfinite irregular waveguide]. Differents. Uravneniia, 19, 4, 603-607 [in Russian]. 
2 Kabanikhin, S.I. (1978).Obratnye zadachi dlia hiperbolicheskikh uravnenii i konechno-raznostnye metody ikh issledovaniia [Inverse problems for hyperbolic equations and finite-difference methods for their study]. Diss. kand. fiz.-mat. nauk. Novosibirsk [in Russian].

3 Romanov, V.G., \& Kabanikhin, S.I. (1991) Obratnye zadachi heoelektriki /On one problem of wave propagation in a semi-infinite irregular waveguide]. Moscow: Nauka [in Russian].

4 Kabanikhin, S.I., \& Iskakov, K.T. (2001). Optimizatsionnyi metod resheniia koeffitsientnykh obratnykh zadach [An optimization method for solving coefficient inverse problems [Optimization method for solving coefficient inverse problems]. Novosibirsk: NHU [in Russian].

5 Romanov, V.G., \& Moshkalev, P.S. (2011). Odnomernaia obratnaia zadacha ob opredelenii istochnika tsunami [One-dimensional inverse problem of determining the tsunami source]. Sibirskii zhurnal industrialnoi matematiki, 14, 3, 87-99 [in Russian].

6 Mukanova, B.G., \& Romanov, V.G. (2016). Inverse source problem for wave equation and GPR data interpretation problem. Eurasian Journal of Mathematical and Computer Applications, No. 3, 15-28.

7 Iskakov, K.T., Tokseit, D.K., Oralbekova, Zh.O. \& Mirgalikyzy, T. (2019). Creation and testing of a new mathematical software for processing georadar data. Eurasian Journal of Mathematical and Computer Applications, 7, 4, 86-99.

8 Romanov, V.G. (1986). O strukture fundamentalnoho resheniia zadachi Koshi dlia sistemy uravnenii Maksvella [On the structure of the fundamental solution of the Cauchy problem for the system of Maxwell equations]. Differents. uravneniia, 19, 4, 603-607 [in Russian].

9 Akhmetov, O.I., Mingalev, V.S., Mingalev, I.V., \& Mingalev, O.V. (2018). Reshenie zadachi Koshi dlia trekhmernoho telehrafnoho uravneniia i tochnye resheniia uravnenii Maxvella v odnorodnom izotropnom provodnike s zadannym istochnikom vneshneho toka [Solution of the Cauchy problem for a three-dimensional telegraph equation and exact solutions of Maxwell's equations in a homogeneous isotropic conductor with a given source of external current]. Zhurnal vychislitelnoi matematiki i matematicheskoi fiziki, 58, 618-625 [in Russian].

10 Cannon, J.R., \& Chateau, P.Du. (1983). An inverse problem for an unknown source term in a wave equation. SIAM Journal on Applied Mathematics, 43, 3, 553-564.

11 Chapouly, M., \& Mirrahimi, M. (2012). Distributed source identification for wave equations: An off-line observer-based approach. Automatic Control, IEEE Trans, 57, 8, 2076-2073.

12 Deguenon, J., Sallet, G. \& Xu, C.-Z (2006). Infinite dimensional observers for vibrating systems. in Proc. IEEE Conf. on Decision and Control, 3979-3983.

13 Isakov, V. (1990). Inverse Source Problem Mathematical Surveys and Monographs. - American Mathematical Society, 34.

14 Kabanikhin, S.I. (2011). Inverse and Ill-Posed Problems Theory and Applications, De Gruyter. Germany.

15 Kabanikhin, S.I., \& Satybaev, A.D. \& Shishlenin M.A. (2004). Direct Methods of Solving Multidimensional Inverse Hyperbolic Problem VSP. - Utrecht.

16 Kabanikhin, S.I., \& Iskakov, K.T. (2007). Inverse and ill-posed problems for hyperbolic equations. KazNPU, Almaty.

17 Beilina, L., \& Klibanov, M.V. (2007). Approximate Global Convergence and Adaptivity for Coeffcient Inverse Problems. New York: Springer.

18 V de Hoop M, \& Tittel?tz J. (2015). An inverse source problem for a variable speed wave equation with discrete-in-time sources. Inverse Problems, 1, 7, 075007.

19 Symes Rakesh, W.W. (1988). Uniqueness for an inverse problem for the wave equation Communications in Partial Differential Equations, 13, 87-96. 
20 Romanov, V.G., \& Kabanikhin, S.I. (1994). Inverse Problems for Maxwell's Equations. Utrecht, The Netherlands: VSP.

21 Tikhonov, A., \& Arsenin, V. (1977). Solution of Ill-Posed Problems. Wiley, New York.

22 Hasanov, A. (2009). Simultaneous determination of source terms in a linear hyperbolic problem from the final overdetermination: weak solution approach. IMA Journal of Applied Mathematics, 74, 1-19.

23 Engl, H.W, Scherzer, O. \& Yamamoto, M. (1994). Uniqueness and stable determination of forcing terms in linear partial differential equations with overspecified boundary data. Inverse Problem, 10, 1253-1276.

24 Yamamoto, M. (1995). Stability, reconstruction formula and regularization for an inverse source hyperbolic problem by a control method. Inverse Problems, 11, 481-496.

25 Stolt, R.H. (1978). Migration by Fourier transform. Geophysics, 43, 1, 23-43.

26 "Ozdemir, C., Demirci, Ş, Yiğit, E., Yilmaz, B. (2014). A Review on Migration Methods in BScan Ground Penetrating Radar Imaging. Mathematical Problems in Engineering 6, Article ID 280738. Retrieved from http://dx.doi.org/10.1155/2014/280738. .

27 Tikhonov, A.N., \& Shahsuvarov, D.N. (1956). Method for calculating electromagnetic fields excited by alternating current in layered media. Doklady AN, ser. Geophysical, 3, 251-254.

28 Dmitriev, V.I. (1968). General method for calculating the electromagnetic field in a layered medium. Computational methods and programming, 10, 55-65.

29 Dmitriev, V.I., \& Fedorova, E.A. (1980). Numerical studies of electromagnetic fields in layered media. Computational methods and programming, 32, 150-183.

30 Karchevsky, A.L. (2005). A numerical solution to a system of elasticity equations for layered anisotropic media. Russian Geology and Geophysics, 46, 3, 339-351.

31 Karchevsky, A.L (2005). The direct dynamical problem of seismics for horizontally stratified media. Siberian Electronic Mathematical Reports, 2, 23-61. Retrieved from http://semr.math. nsc.ru/v2/p23-61.pdf.

32 Karchevsky, A.L. (2007). AA frequency-domain analytical solution of Maxwell's equations for layered anisotropic media Russian Geology and Geophysics, 48, 8, 689-695.

33 Karchevsky, A.L., \& Rysbayuly, B.R. (2015). Analitical expressions for a solution of convective heat and moisture transfer equations in the frequency domain for layered media. Eurasian Journal of Mathematical and Computer Applications, 3, 4, 55-67.

34 Smirnov, V.I. (1974). Kurs vysshei matematiki [The course of higher mathematics]. Moscow: Nauka [in Russian]. 